\title{
Present Political Scenario of Jammu and Kashmir and the Role of Current Collation Government of P.D.P and B.J.P
}

\author{
Johar Zaman
}

\author{
Research Scholar of Govt. Hamadia Arts and Commerce College Bhopal
}

\begin{abstract}
This paper looks at the political development of Jammu and Kashmir and the present hung government and its agendas' for future development. Nearly all the major countries of Asia are undergoing through the change by the means of globalization, modernization and the Changing global balance of power which is transformed from the international environment same I found in the state of Jammu and Kashmir besides this, the Assembly election in the state is now the matter of the electoral competition. Although each election since 2002 had been highly competitive with NC National conference, Peoples democratic party PDP and congress each of these political parties claims for the power and other parties like the Bharatiya Janta Party BJP and Panthers party where not in position for rule in the state but in the parliamentary election 2014 the system of competition changed in this election BJP got three and PDP got three seats out of all six and two collation partners of that time N.C and Congress remains at null position, meanwhile same was the case with the assembly election 20014 in which PDP emerge as largest party with 28 seats followed by BJP with 25 seats and make the collation government. Now the people of state are expecting the future development in all the three divisions of the state that is why they are participating in the affairs of government by the means of their political right (Right to vote).
\end{abstract}

Keywords: $J$ \& $k$ politics, parties competition in election, Right to vote, Future Development of state, Assembly election 2014

\section{INTRODUCTION}

The Jammu and Kashmir state had been consisted of three political regions. Including Ladakh towards the east shearing its border with China, Jammu towards the south shares its border with the states of Hamichal Pradesh, Punjab and Pakistan, Kashmir Valley towards the west bordering with Pakistan occupied Kashmir as same with the other states of India, Indian controlled parts of Jammu and Kashmir have a multi-party democratic system of governance. The Main political parties in the state of Jammu and Kashmir are People's Democratic Party (PDP), Bharatiya Janta Party(BJP).National Conference (NC),Indian national congress (INC) .But in the assembly elections of 2014 the state of Jammu and Kashmir saw a good voter turnout of $65 \%$ (which is good indication of common people participation in the government by their political right) PDP remains at the top with 28 seats .the second largest party was Bharatiya Janta Party with 25 seats in the state legislature assembly of 87member house.

\section{PDP AND BJP COLATION GOVERNMENT}

The formation of the BJP and PDP collation government with Mohammad Sayeed a 79 year old politician and the collation partner as a chief minister and with the two months of hard negotiations between the both political parties based on the common minimum program (CMP) The main objective of this alliance is the agreement which says would be best for making peace, harmony and confidence building within the state and across the LoC for full development of democracy through inclusive politics. Also the collation should create such type of conditions and platform which would facilitate resolution of all issues which are obstacles in the development of the state. So the hung government of Jammu and Kashmir will initiate a system of meaningful dialogue with all the separatist leaders irrespective of their ideological views which will seek to build a broad-based consensus on the resolution of all outstanding issues. Besides this the government has recently initiated several steps to normalize the relationship with the neighboring country Pakistan, the present coalition government will seek to support and strengthen the approach. By developing the civil Society exchanges and by making a good system of trade and commerce and business across the LoC to the next level 


\subsection{Political Measures of Collation Government of BJP and PDP}

The central Government of India had initiated some measures to normalise the bitter relation with the neighboring country Pakistan. The present Hung government will follow the union government and also supports the measures which should be taken by the union government to create such type of environment that will build stakes for all in the peace and development within the sub continent. The political development of the state is only possible if both the collation partners will take confidence building measures including, people to people contact on both sides of the LoC and opening of new routes across all three regions of Jammu and Kashmir to improve the connectivity

The present collation government will also keep its eyes on the process of dialogue with all political groups, including the Hurriyat Conference, in the spirit of "Insaaniyat, Kashmiriyat aur Jamhooriyat

This political measure will seek to build a broad based consensus on resolution of all the remaining issues of state Jammu and Kashmir

\subsection{The Security Measures by the Collation Government}

The present scenario of Jammu and Kashmir has improved too much from that of 1990s so far as security point of view is concerned the collation government will work to build greater public confidence in its sustainability. The entire public of the State of Jammu and Kashmir are now able to understand the value of peace and normalcy in the state. In the security matter the present coalition government will see the security situation in the state systematically with a view to examine the need and desirability of all the special laws being applied to the state in view of the situation which is improving.

The both political parties of collation government have historically the difference of opinion regarding the Armed Forces Special Powers Act (AFSPA) and its need in the State. At present Arms force special power act is a matter of agenda for governance of this alliance, the present collation partners will see the disturbed areas of the state and make important changes as per the need of common masses of the state with informing and getting into confidence with the union government of the country.

The lands that are acquired by the security forces in the state without any lease and licenses under the provision of the Land Acquisition Act will be returned to the rightful legal owners, except in a situation where retaining the lands is absolutely imperative in view of a specific security requirement. In any case, monetary remuneration, be it in the form of rents or compensation should be made fairly at market rates

\section{OBJECTIVES}

1. To know the role of collation government in developing the political prospective

2. To highlight the agenda of collation government for all the three divisions of the state

3. To explain the peoples participation in the election 2014

4. To examine the security and political measures of both the collation partners

\section{MeThodology}

The information for this paper has been primarily collected from the secondary sources that are:-

Books

Journals

News papers and government reports

Internet

\section{Highlights of PDP-BJP Government Agenda in Jammu and Kashmir}

The collation government of Jammu and Kashmir has prepared a common minimum programme keeping in mind the people's mandate. 
Here are the 15 highlights of the CMP:

1. In order to make the political development of the state it is important for both the collation partners to create an environment of peace, certainty and stability.

2. The present government should be transformed in to smart government which would be transparent as well as accountable

3. It is also the mission of the collation government that Jammu and Kashmir should be ethical rather than a corrupt state

4. The present government of the state look overall economic policy which will align the economic structure of the state

5. The present government must ensure the autonomy of institutions of probity which include the state accountability commission, vigilance commission and also gives rise to Right to information act.

6. The government should fallow the principle of insanity, Kashmirit and Jamhooriyat which was laid by earlier prime minister of National Democratic Alliens (NDA) Atal Bihari Vajpayee .The state government will also make a meaningful dialogue with the internal stakeholders which include political groups irrespective of their ideological views

7. The collation government of the state will examine the need to see the disturbed areas which will as a consequence enable the central government to take the final decision on the continuation of Arms Force Special Power Act in such areas

8. As per the current collation government Article 370: the present position will be maintained including the special status.

9. The collation government will also facilitate the dialogue with the Hurriyat Conference irrespective of their ideological views

10. The lands that are acquired by the security forces in the state without any lease and licenses under the provision of the Land Acquisition Act will be returned to the rightful legal owners, except in a situation where retaining the lands is absolutely imperative in view of a specific security requirement. In any case, monetary remuneration, be it in the form of rents or compensation should be made fairly at market rates

11. The collation government will work on the refugees of the Pakistan occupied Kashmir of 1947, 1965 and 1971 respectively and gives one time settlement.

12. The collation government will also take the suitable measures for the livelihood of the western Pakistan refugees

13. The government will also extend the benefits to those people who are living on line of control (LoC) and people living on international borders.

14. The government will secure the share of profit of National Hydro Power Project (NHPC) emanating from Jammu and Kashmir's water to the state government.

15. The collation government will reserve all royalty agreement with NHPC.

\section{CONCLUSION}

From the above it is concluded that the present hung government is trying to develop all the three divisions of Jammu and Kashmir by making the common minimum program (CMP), It also lead the political development of the state by creating peace and harmony among the citizens of all the three divisions and also keep eyes to maintain good relation with the Pakistan

\section{REFERENCES}

Election in Jammu and Kashmir: Government of India news papers The Hindu, Grater Kashmir, Times of India

Journals: India Today, The Outlook, Welcome to the frontline Vol 29

Sumantra Bose: Challenges to the World's Largest Democracy

Chowdhary Rekha: Electoral politics in the context of separatism and political divergence, an analysis of parliamentary election 2009 